ECONOMICS

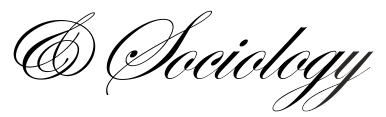

\author{
Maria Piotrowska, \\ Wrockaw University of Economics, \\ Wroctaw, Poland, \\ E-mail: \\ maria.piotrowska@ue.wroc.pl \\ Marek Kośny, \\ Wroclaw University of Economics, \\ Wroctaw, Poland, \\ E-mail:marek.kosny@ue.wroc.pl
}

Received: December, 2016

1st Revision: March, 2017

Accepted: June, 2017

DOI: $10.14254 / 2071-$

789X.2017/10-3/4

JEL Classification: J62, P36
Piotrowska, M., Kośny, M. (2017). Economic Transition and Intergenerational Mobility in Poland. Economics and Sociology, 10(3), 59-71. doi:10.14254/2071789X.2017/10-3/4

\section{ECONOMIC TRANSITION AND INTERGENERATIONAL MOBILITY IN POLAND}

\begin{abstract}
The main aim of the article is to examine intergenerational mobility in the context of relative assessments of financial situations. Using data from the dedicated survey and the mobility measure based on transition matrixes, we try to answer two questions concerning intergenerational mobility in Poland. The first one is whether this phenomenon was affected by the political transformations that took place in Poland in the early 1990s. And the second one is how economic transition affected the financial situation mobility among women. The results show the impact of economic transition on the level of intergenerational mobility and much better adaptation of younger cohorts to market requirements, particularly among women.
\end{abstract}

Keywords: mobility, generations, transition.

\title{
Introduction
}

The issue of mobility is one of the central problems in the context of changes that are taking place in contemporary societies. The increasing attention paid to this issue stems from the fact that mobility provides an opportunity to achieve higher social status in a way that is as little as possible determined by the material, professional and social status of one's parents. And - as a consequence - it testifies to the openness of societies (see, for example, Blau and Duncan, 1967; Erikson and Goldthorpe, 1992). High mobility is traditionally seen in literature as lack of institutional barriers to personal development.

Examining intergenerational mobility, economists and sociologists focus on the relationship between financial status, occupation or attained education level of two generations, most often fathers and sons (see, for example, Broom and Jones (1969) for the United States, Australia and Italy; Meyer, Tuma and Zagórski (1979) for Poland and the United States; Azam and Bhatt (2015) for India; Modalsli (2017) for Norway). Financial status is usually measured by earnings or income (individual or household). The concept of intergenerational mobility, adopted in this analysis, refers to a positional change, which is understood as the difference between the position of a child - not in terms of his/her wealth per se, but in terms of his/her rank in population - and the position of his/her parent.

Mobility, including intergenerational mobility, is largely preconditioned by traditions and situation inside the country. Countries characterized by the lowest mobility are countries in which social roles are mostly preconditioned by personal origin. A typical example is India (especially when it comes to lower castes - see, for example, Azam, 2016). On the other hand, there are countries largely based on the idea of welfare state. Universal access to education, 
regulations that promote equality at markets, including labor market first of all, provide vast development opportunities for all who want to actively develop themselves. Countries traditionally classified to this group are, for example, Scandinavian countries (see Bratberg et $a l ., 2017)$. The analysis presented in this article concerns Poland - a country located somewhere between these two extremes (see Mach, 2014; however, hardly no comparable data is available - see Nunn, 2011).

The main aim of this article is to examine intergenerational mobility in terms of relative assessments of wealth. The analysis, however, is not intended to answer the question what is the level of this phenomenon in Poland, but whether and how this phenomenon was affected by the socioeconomic development in Poland since 1990. We consider two stages of this development. The first one concerns transition from a centrally planned economy to a market economy during 1990-2004, and the second stage is after Poland's accession to the European Union: it can be assumed that since 2005 there has been market economy in Poland. Radical socioeconomic changes which resulted from transition and further development of the market economy have created a variety of opportunities to improve the financial status of various cohorts.

Our main contribution to the research on intergenerational mobility is to analyze this phenomenon from the perspective of cohorts that differed in possibilities of improving their financial status. Such an approach can undermine - in the specific context of socioeconomic transition in Poland - the main conclusion of the life cycle hypothesis which indicates that wealth level should improve with age, at least until the age of retirement.

To illustrate this approach, let us consider two cohorts of two-generation families, older and younger, and appropriate scenarios of changing their financial status with age. Let us assume that children in each cohort have higher education.

In the older cohort, in 1990, children were 13-19 years old, so they started their education in the reformed secondary schools and universities already, thus obtaining qualifications which are useful in today's market economy. Wealth in the generation of children in this cohort should grow with age. On the other hand, their parents entered the transition processes with the skills acquired during the centrally planned economy and thus had limited employment opportunities in newly established private companies, especially foreign corporations. This generation of parents was rapidly hit by high unemployment rates in the first half of the nineties. Larger share of this generation has not accumulated financial assets and its relative financial status should decline with age. As a confirmation of this scenario may serve high intergenerational mobility, reflecting the overwhelming majority of children whose relative wealth is higher than the relative wealth of their parents.

In the younger cohort, children were only beginning their lives at the beginning of the transformation period. These children graduated from universities within market economy, and entered the labor market with proper skills which allow them take advantage of the offers of both international corporations and national companies. Their parents entered the transformation as young people (being 19-34 years old back in 1990), some of them were still studying while others could took advantage of the opportunities to improve their qualifications. This generation of parents (at least its huge part) was young enough to benefit from the transformations and to improve their financial status. But how do they manage within market economy, as compared to their children? If the prevailing percentage of children, despite their young age (who are now 24-31), judges their relative wealth as high or higher than their parents (45-60 years), then it would indicate that children are able to exploit the opportunities of the market economy much better than their parents. And that parents improve their financial status more slowly than their children. 
Studying the relative wealth of two-generation families should provide results that allow for a verification of the above scenarios of an impact of the socioeconomic development on intergenerational mobility.

Taking cohorts into account in this study also sheds more light on gender differences in intergenerational mobility. In literature, father-son dyads most often are studied, much less attention is given to mothers-daughters, and very rarely - to dyads father-son and fatherdaughter simultaneously. The cohort analysis concerning gender differences is not known to the authors. In our study, such analyses will allow answering two questions.

First, are there cohort differences between daughters and sons in a range of improvement of their wealth situation, as compared to their fathers or mothers? Let us consider two examples. If in a given cohort, daughters are clearly more mobile than sons, and additionally this mobility is associated with the improvement in their material status, it would suggest that in poorer families with lower material status, daughters were more likely to escape from poverty (usually by getting higher education). Or did parents invest more in the education of sons or daughters? If more sons than daughters achieve higher financial status than their parents, this suggests differences in this area.

Secondly, taking cohorts into account allows answering questions concerning the impact of socioeconomic development on the changes in the situation of women. Does the rise in the level of education and professional skills among the youngest group of mothers reduce the mobility of their daughters (in mother-daughter dyads) as compared with older cohorts, where mothers have lower levels of education and professional activity?

The advantage of the cohort approach is that it is possible to use the results of intergenerational mobility analysis to assess the chances of different groups to increase their wealth by making use of possibilities generated by socioeconomic development. If subsequent generations of children obtain higher financial status than their parents, and the younger generations attain the level of wealth of their parents at even younger age, the direction of change in the economy is right. Based on the results of our study, we cannot formulate such an unambiguous conclusion as the study concerns children with higher education and it does not necessarily translate into the mobility of other social groups.

It is worth stressing here that the purpose of the analysis is not to assess the absolute level of mobility, which would allow, for example, international comparison, but to identify differences in the mobility between the analyzed groups of individuals.

The rest of the article is divided into 5 parts. In the next two sections, we present, respectively, broader explanation for taking this particular topic and the attempt to show the current state of the art in this area. In the following section, we present the data set and methods used for the analysis. The next section provides presentation and interpretation of the empirical results. The last section concludes.

\section{Motivation}

The motivation for undertaking the research on intergenerational mobility in Poland are changes in society and the economy that have occurred under the influence of transition from a centrally planned economy to a market economy. These changes provide an unique opportunity to examine how the socio-economic development can change the economic situation of children compared with their parents.

The first stage of transition took place in the 1990s, the second one covered the years 2000-2004 and it was aimed at the ultimate preparation of Poland to the EU accession in 2004. Since 2005, Poland has developed in a direction of an advanced market economy, although it still belongs to a group of emerging markets. The transition has resulted in three great changes in the economy and the society: 1) dynamic growth of private sector (private sector generates 
most of the GDP, small and medium size enterprises create the majority of jobs), 2) openness of the economy (FDI growth, high technology, the western style of management not only in foreign firms but also in domestic ones, two millions of Poles have found jobs abroad), and 3) very dynamic growth in a share of high educated people (a share of people aged 15-64 with a tertiary level of education increased from $7.7 \%$ in 1995 to $2.2 \%$ in 2016 ; for men from $7.8 \%$ to $20.3 \%$, while for women from $6 \%$ to $30.1 \%^{1}$ ) as well as a considerable increase in births by mothers with a tertiary educational level in total number of births (a percentage of mothers with a tertiary educational level increased from $6 \%$ in 1990 to $49.4 \%$ in 2014, while a percentage of mothers with primary education/or even without any educational level attained, declined in this period from $18 \%$ to $3.7 \%{ }^{2}$ ).

Economic transition generated various possibilities for education and professional development for individuals and thus various possibilities for improving their situation. This allows examining the effect of non-family factors on intergenerational mobility across cohorts as well as the identification of gender differences. In the next, cohorts will be defined according to the period of finishing of university education and entering the labor market (before 1990, after 1990; university studies in the 90s or after 2004).

\section{Literature review}

The concept of intergenerational mobility usually refers to a positional change, which is understood as the difference between the position of the child in the distribution of children's income and the position of the parent - in the distribution of parents' income ${ }^{3}$. Standardization for such changes is most easily accomplished by summarizing each person's position not in terms of their income per se but in terms of their rank in the population normalized by the population size: the marginal distribution of these 'fractional' (or 'normalized') ranks is a standard uniform distribution for both parent and offspring. Changes in income affect positional mobility only when these changes alter each person's position relative to the position of others. Equiproportionate income growth or equal absolute additions to income for everyone raise incomes but there is immobility in the positional sense (see Jäntti and Jenkins, 2014).

Greater mobility, understood as less association between generations, has long been linked with having a more open society: less dependence between the starting point and the actual situation is said to entail higher equality of opportunity (see Blau and Duncan, 1967; Erikson and Goldthorpe, 1992; Nunn, 2011). Origins refer to the parental situation - their income, occupation, social position. The specific aspect, to which the analysis refers, is related to the discipline in which the analysis is carried out. The problem of mobility between generations was initially analyzed from the sociological point of view within the concept of social mobility (see, for example, Lipset and Bendix, 1964). The concept of mobility was later gradually transferred to the area of economics - initially in the context of income mobility (see Shorrocks, 1978). This area, however, was later significantly expanded to other aspects consumption, occupation, and education (see, for example, Becker, 1981; Becker and Tomes, 1986), thus approaching the area characteristic for sociology.

The availability of empirical results for intergenerational mobility levels varies widely between countries. The specificity of the requirements for data sets that would allow such analyses makes assessment and comparison of intergenerational mobility possible in very few cases. The first, relatively broad panel study was initiated in the US in the 1960s (Panel Study of Income Dynamics). In other countries, this type of research has been started many years later

\footnotetext{
${ }^{1}$ Source: Bank Danych Lokalnych, Central Statistical Office (https://bdl.stat.gov.pl/BDL, accessed 15.08.2017).

${ }^{2}$ Source: Central Statistical Office 2015, Table 73, p. 289.

${ }^{3}$ In the literature there are distinguished four concepts of economic mobility: positional change, individual income growth, reduction of longer term inequality, and income risk (see Jenkins, 2011).
} 
(for example, in Poland, panel data on different aspects of life, is gathered within Social Diagnosis, carried out systematically since 2000), and in most developing countries such studies are not carried out at all. Therefore, there are very few comparative analyses in the field of economics, especially for larger groups of countries (there are comparisons of several countries - see, for example, Nunn, 2011; Bratberg et al., 2017). Because of the availability of relevant data, existing comparative analyses do not include Poland (but also most developing countries and former communist countries), which makes it difficult to clearly identify Poland's position from the point of view of intergenerational mobility. There are also few analyses of this phenomenon with regard to Poland itself (see Domański, 2004; Mach, 2004; Sokołowska, 2013). This problem is not easy to solve - historical panel data cannot be obtained. Therefore, this article uses a specifically designed cross-sectional study whose characteristics are presented in the next section.

As already mentioned, in the last years, the economic analyses of intergenerational mobility concentrated on the problems much broader than income - in particular, issues of the impact of education on intergenerational mobility attracted much attention. Black and Devereux (2011) point out that researchers dealing with intergenerational mobility shifted their focus from the measurement of the phenomenon (for example, Jäntti et al. (2006) who compare the rate of intergenerational mobility between countries) to the mechanisms that generate them. Education is one of them. Gregg et al. (2013) carrying out international comparisons underline the diversity of the return on education which generates the income gap between the generations.

Particular attention was also drawn to the intergenerational impact of education, showing that part of the return to education, which children obtain in the form of earnings, depends on the education level of their parents (Black et al., 2005).

Many studies are devoted to the role of the family in shaping the human capital of children (see, for example, Björklund and Salvanés, 2011; Currie and Almond, 2011; Heckman and Mosso, 2014). Most frequently studied aspect of the role of the family is the parents' education and its impact on the child. The results indicate a positive causal effect of mother's education (Chevalier, 2004; Carneiro et al., 2013) as well as the education of the father (Black et al., 2005). Carneiro et al. (2013) indicate significant intergenerational returns from education, showing that an extra year of mother's education increases the level of education of the child and reduces problems related to his upbringing.

Therefore, in this paper, we will make an attempt to show the possible explanations for the observed differences in the intergenerational mobility.

\section{Data and methods}

The analysis of intergenerational relations is largely limited by the availability of relevant data. The full assessment would require gathering complete information about all people associated with the household (even if it ceases to be a member of this household) over the decades. In practice, such a requirement is usually difficult to meet. Only a few panel research allow for this type of direct assessment, among others the Panel Study of Income Dynamics $^{4}$ and the German Socio-Economic Panel ${ }^{5}$. In other cases, emerging issues relate mainly to the possibility of observing a person's income over the years, especially when it creates a separate household. Another problem is also often recording of individual income of each household members.

\footnotetext{
${ }^{4}$ Longitudinal household survey conducted in the United States since 1968 (https://psidonline.isr.umich.edu/, accessed 15.08.2017).

${ }^{5}$ Longitudinal household survey conducted in Germany since 1984 (https://data.soep.de/soep-core, accessed 15.08.2017).
} 
In the absence of the availability of relevant data, this type of practical problems is solved by reducing the scope of the analysis. One possible solution is to observe the changes of the reference person in the household (over the years), which allows for assessment of the amount of income of the next generation. In this case, the specificity of the sample, for which the analysis is performed, becomes the apparent problem: we assume the continuity of observation of the both generations, which means the direct relation between parents and children (in particular, cohabitation in common household). Such relationships negatively impact the quality of the data and the generalizability of the results. Adults living in the same household with their parents constitute a specific group, which is surely not representative for the whole population.

Another solution to the problem of data availability are attempts of estimation the relevant variables. In a situation where the relevant data is available to one person in the parentchild pair, respective value for the second of them can be estimated on the basis of other available data, for example gender, age or education level.

Another problem is the issue of the moment of observation. Usually, goals of the study determine that we compare the characteristics of parents and children at a time when they were the same age, or we compare values obtained in one period. The first of these types of analyses requires panel data for a very long period. In this case, very important are also issues, indicated earlier, related to the identification of the parent-child pairs. Of a great importance is also the appropriate unification (adjustment) of variables, especially those expressed in monetary units. Such an analysis, however, allows for the observation of the next generations in similar conditions.

The second group of analyses involves the use of cross-sectional data. In this case, the results may be based on the estimated data, what is associated with the risk of large inaccuracies. They can, however, relate directly to the actual responses. In such a situation, however, we describe the situation of two people at different stages of life.

This approach has been applied in this article. Observation of the successive generations at different stages of their lives does not require panel data, and - at the same time - fits very well with the purpose of the analysis, which is to assess the extent to which political transformation affected the financial situation of specified cohorts. The problem which excluded usage of standard data sets (EU-SILC ${ }^{6}, \mathrm{HBS}^{7}$ ), was a necessity of simultaneous surveying of both generations - children and their parents. The standard data sets for which the basic unit is the household, limit the ability to analyze data on parents and children to a situation where two individuals are part of the same household. As already mentioned, such restriction involves the risk of very large bias. In Poland, approximately $17 \%$ of adults live together with their parents (in one household) ${ }^{8}$.

To obtain the appropriate sample structure, in which it will be possible to identify the child-parent dyads, we decided to carry out a dedicated survey. In this study, we divided generation of children into three groups: aged 25-31, 32-38 and 39-45. As indicated before, the choice of age intervals was determined by the age of the respondents at the time of political transformation (in 1989-1991, after the fall of communism, there has been a transition from a centrally planned economy to a market economy). The youngest group was then in the preschool period. The second group covered persons attending the primary school at that time. The third group consists of persons who were in their teens. An additional requirement, essential

\footnotetext{
${ }^{6}$ Household survey, based on rotating panel, conducted in the European Union since 2003 (http://ec.europa.eu/eurostat/web/microdata/european-union-statistics-on-income-and-living-conditions, accessed 15.08.2017).

${ }^{7}$ Household Budget Survey, based on rotating panel, conducted in Poland since 1956 (http://stat.gov.pl/cps/rde/xbcr/gus/WZ_meto_badania_bud_gospod_dom.pdf, accessed 15.08.2017).

${ }^{8}$ According to the results of the 2011 Census (Central Statistical Office 2014, Table 11).
} 
from the point of view of the purpose of the study, was to narrow the group of respondents to persons with tertiary education. This is due to the need to obtain (assuming that the total sample size is preset) relatively homogeneous population of "children", whose efficiency on the market will be explained by different characteristics of their parents.

For each of the age group defined in a way described above, approximately 300 respondents were drawn. Sampling was carried out by the Central Statistical Office based on a TERYT system (the method used in official, representative surveys in Poland). Main survey research was conducted using CAPI method by the renowned, independent research agency ${ }^{9}$ in the period from October to December 2016. Main research was preceded by the pilot study (covering 110 persons) in September 2016 which allowed for testing and improving the questionnaire (some questions proved to be not clear enough to respondents). Each of the 902 randomly selected persons was interviewed along with a parent - mother or father ${ }^{10}$. In this way, the basic unit of study were child-parent dyads. The aspect controlled for the entire sample was the fact of living in a common household. This was to ensure the proper percentage of people living in a common household with their parents consistent with the percentage of such people in the population. The structure of the sample is presented in Table 1.

As mentioned in the introduction, this study design does not allow for a direct comparison of the results obtained with regard to mobility levels with results obtained for other countries. An absolute assessment of this level, which would make this type of comparison possible, is not an objective of this analysis. The aim is to evaluate the relationships and relative differences between the analyzed cohorts.

Table 1. Sample structure

\begin{tabular}{cccccccc}
\hline & \multicolumn{6}{c}{ Number of children-parent dyads surveyed } \\
\cline { 2 - 8 } & $\begin{array}{c}\text { Whole } \\
\text { sample }\end{array}$ & $\begin{array}{c}\text { Father- } \\
\text { Son }\end{array}$ & $\begin{array}{c}\text { Father- } \\
\text { Daughter }\end{array}$ & $\begin{array}{c}\text { Mother- } \\
\text { Son }\end{array}$ & $\begin{array}{c}\text { Mother- } \\
\text { Daughter }\end{array}$ & $\begin{array}{c}\text { Parents with } \\
\text { tertiary } \\
\text { education }\end{array}$ & $\begin{array}{c}\text { Parents } \\
\text { still } \\
\text { working }\end{array}$ \\
\hline All cohorts & 902 & 156 & 156 & 204 & 386 & 136 & 350 \\
\hline Cohort 1 & 301 & 57 & 40 & 84 & 120 & 59 & 195 \\
\hline Cohort 2 & 300 & 54 & 52 & 72 & 122 & 44 & 113 \\
\hline Cohort 3 & 301 & 45 & 64 & 48 & 144 & 33 & 42 \\
\hline
\end{tabular}

Source: own calculations based on the results of the survey research.

To describe own financial situation, the respondents used a 5-step scale. Therefore, an adequate assessment of mobility includes measures that are based on transition matrixes (as the choice of the method of an analysis strongly depends on the structure of the data).

The basic measure, which will be used in subsequent analyses, is the Shorrocks index of Normalized Trace, given by the formula (see Shorrocks, 1978):

$$
N T=\frac{n-\operatorname{trace}(A)}{n-1}
$$

\footnotetext{
${ }^{9}$ The research agency responsible for designing, organizing and conducting the survey was the consortium of companies DANAE Sp. z o.o. and REALIZACJA Sp. z o.o.

${ }^{10}$ Interviewers were required to survey both persons from each dyad (a child and a parent) separately in a way excluding the presence of another person.
} 
where $A$ is the transition matrix with $n$ income classes and $\operatorname{trace}(A)$ is the sum of the transition proportions on the leading diagonal of $A$. This index equals 0 for complete immobility case (where $\operatorname{trace}(A)=n$ ) and 1 for perfect mobility (origin independence). Shorrocks index allows for assessment of mobility when a financial situation is represented as a discrete variable (for continuous variables, set of available methods of the analysis would be much broader).

Regardless of the estimated level of mobility, to assess changes in the financial situation of parents and children we need the information on the asymmetry between changes which are in favor of children and changes in favor of parents. As a measure of this asymmetry, we adopted the difference between the percentage of dyads in which the situation of the child is better than the situation of a parent and the percentage of dyads in which the situation of the parent is better. Positive values indicate the relative improvement of the situation of children in relation to their parents.

\section{Results and discussion}

The sample, constructed in the way described in the previous section, allows for the assessment of the situation of children and parents in the same period. It entails that referring directly to the financial variables (for example, individual or household income) would require making far-reaching adjustments, taking into account, among others, life cycle stage or the stability of the declared income in the long term.

To avoid these problems, we decided to evaluate the affluence on the basis of the information on the perception of one's own situation in a relative manner, when compared to the rest of the population. The obvious limitation of such analyses is their subjective character. On the other hand, they allow for direct comparisons between cohorts of parents and children.

Usage of respondent's own assessment of his/her level of relative wealth as an estimate of a financial situation appears to have advantages mainly from the point of view of the complexity of the obtained information. Respondents were asked to answer the question: "How would you assess the level of your wealth in comparison to the total population of your city/town/village?" by choosing a value from 1 to 5 (higher values meant better relative assessment of the financial situation).

Answers to this question describe the overall financial situation, which covers both current income and accumulated assets. The resulting estimates, however, cannot be identified with any of these aspects. Although the amount of income earned grew on average with an increase in the own assessment of the financial situation, the correlation (statistically significant at the 0.01 level) between income variables (personal and household income) and own assessment of the financial situation for groups of both children and parents ranged between 0.25 and $0.32^{11}$.

The direct reference to the total population of the city/town/village in the analyzed question was intended to clearly define the reference population. It is, however, worth stressing that it did not result in a clear distortion of the data: an analysis of the relationship between the declared assessment of own financial situation, the amount of earned income and the size of the place of residence (and the other demographic characteristic such as gender and level of education) did not show clear linear dependence.

Assessment of own financial situation does not show a clear relation with an age, too. They are systematically higher for generations of children (3.11) than for the generation of parents (2.74). For the generation of children it achieves the smallest value (3.00) in a first age

\footnotetext{
${ }^{11}$ For sub-group of children it was equal to 0.28 and 0.24 for individual (question: What is your personal monthly net income?) and household (question: What is the monthly income of your entire family, together with your own?) income, respectively. For sub-group of parents: 0.28 and 0.31. All these values were, however, statistically significant - because of the sample size (see Kośny and Peternek, 2011).
} 
range and higher in the second and the third (respectively, 3.19 and 3.16), while for the generation of parents it is smaller in the first and the second group (respectively 2.76 and 2.71), while the highest in the third (2.94).

These values clearly indicate the relatively worse situation of parents aged 45-75 (who - at the beginning of the transformation - were aged 19-49). This phenomenon is also evident when the analysis is carried out solely for parents with tertiary education. Differences between children and parents are then smaller but still visible. Apart from the obvious impact of education, this may indicate a relatively weaker capability of these people to adapt to new economic conditions, which were brought by political transformation - most of them had already started their professional activity in the centrally planned economy.

A confirmation of the hypothesis about differences between generations of parents (who started their professional activity before the transformation) and children (who started their professional activity after the transformation) can be found observing the changes in the level of mobility. The results presented in Tables 2 and 3 show changes in the assessment of own financial situation between generations of parents and children. In Table 2 we present mobility levels - Normalized Trace index values. They suggest increasing - with an age - discrepancies between generations. Data from Table 3 indicate the direction of these changes: values presented in this table denote differences, expressed in percentage points, between the percentage of people whose situation has improved compared to the situation of their parents and the percentage of people whose situation has deteriorated.

Table 2. Values of Normalized Trace mobility index for the answers to the question "How would you assess the level of your wealth in comparison to the total population of your city/town/village?"

\begin{tabular}{cccccccc}
\hline & \multicolumn{6}{c}{ Normalized Trace mobility index for subgroups } \\
\cline { 2 - 8 } & All dyads & $\begin{array}{c}\text { Father- } \\
\text { Son }\end{array}$ & $\begin{array}{c}\text { Father- } \\
\text { Daughter }\end{array}$ & $\begin{array}{c}\text { Mother- } \\
\text { Son }\end{array}$ & $\begin{array}{c}\text { Mother- } \\
\text { Daughter }\end{array}$ & $\begin{array}{c}\text { Parents with } \\
\text { tertiary } \\
\text { education }\end{array}$ & $\begin{array}{c}\text { Parents } \\
\text { still } \\
\text { working }\end{array}$ \\
\hline All cohorts & 0.50 & 0.49 & 0.58 & 0.50 & 0.49 & 0.39 & 0.42 \\
\hline Cohort 1 & 0.43 & 0.43 & 0.56 & 0.49 & 0.36 & 0.31 & 0.40 \\
\hline Cohort 2 & 0.49 & 0.47 & 0.51 & 0.48 & 0.52 & 0.37 & 0.40 \\
\hline Cohort 3 & 0.59 & 0.61 & 0.67 & 0.55 & 0.57 & 0.56 & 0.59 \\
\hline
\end{tabular}

Source: own calculations based on the results of the survey research.

Table 3. Differences in an assessment of own financial situation between children and parents

\begin{tabular}{cccccccc}
\hline & \multicolumn{6}{c}{$\begin{array}{c}\text { Differences between the percentage of people whose assessment of own financial } \\
\text { situation has improved compared to the situation of their parents and the percentage of } \\
\text { people whose situation has deteriorated (in percentage points) }\end{array}$} \\
\cline { 2 - 8 } & All dyads & $\begin{array}{c}\text { Father- } \\
\text { Son }\end{array}$ & $\begin{array}{c}\text { Father- } \\
\text { Daughter }\end{array}$ & $\begin{array}{c}\text { Mother- } \\
\text { Son }\end{array}$ & $\begin{array}{c}\text { Mother- } \\
\text { Daughter }\end{array}$ & $\begin{array}{c}\text { Parents with } \\
\text { tertiary } \\
\text { education }\end{array}$ & $\begin{array}{c}\text { Parents } \\
\text { still } \\
\text { working }\end{array}$ \\
\hline All cohorts & 27 & 23 & 33 & 29 & 25 & 18 & 11 \\
\hline Cohort 1 & 17 & 4 & 30 & 20 & 18 & 0 & 11 \\
\hline Cohort 2 & 26 & 28 & 19 & 39 & 20 & 23 & 12 \\
\hline Cohort 3 & 38 & 42 & 47 & 29 & 36 & 42 & 5 \\
\hline
\end{tabular}

Source: own calculations based on the results of the survey research. 
According to the data presented in Table 2, the mobility of own assessments of relative wealth increases with age - both in the whole sample and among those whose parents have tertiary education. At the same time, taking into account the results of Table 3, it is clear that mobility is definitely beneficial to generations of children, what seems to be an important aspect of consequences of observed mobility. It is worth stressing that mobility itself involves movements, but we can easily imagine the situation, in which a scope of decreases is the same as a scope of increases. In such a case high mobility could be neutral in this sense that we would not be able to indicate beneficiaries. Nonnegative values in Table 3, however, indicate a relatively worse situation of parents. It should be emphasized that the results showing a privileged situation of a children's generation persist when we take into account only the people who are currently working or restrict the analysis to parents with higher education. Also, value equal to 0 (Table 3 , for cohort 1 and parents with higher education) should be interpreted in this way.

Cohort 1 includes persons starting their career. According to the life cycle hypothesis, the financial situation of these persons should be relatively worse than their parents who are approaching the end of their career. The results indicate, however, that the situation of this youngest group is not worse, and in many respects better than that of their parents. An explanation of this phenomenon could be sought with respect to the transition. In the 1990s (transition period) parents in cohort 1 were in their mobile age. Their generation was most strongly involved in the implementation of economic transformation. The transition to a market economy (creation of private enterprises, new jobs, the possibility of rapid career advancement) created for them the possibility of rapid growth in relative financial status. Given the unique opportunities created for parents during transformation, despite their young age (under 31 years) children in this cohort evaluate their financial status higher than their parents in $30 \%$ cases.

The situation of cohort 3 is different. When the transformation began, the parents in cohort 3 were in the productive (but immobile) age, with qualifications which were often inappropriate for emerging private enterprises and international corporations. In this group, the rate of improvement in financial status is much lower than for parents in cohort 1. At the same time, children in cohort 3 had an opportunity and time for gathering assets. Having finished their studies in a market economy, their skills were more suited to market requirements. As a result, almost half (49\%) children in cohort 3 evaluates its financial status (relative to other inhabitants of their city/town/village) higher than their parents (for cohort 2, this value is equal to $38 \%)$.

It should be noted that in the literature on mobility, as mentioned earlier, greater mobility is quite unambiguously identified with the greater openness of society and the possibility of easier overcoming barriers resulting from the existing ownership structure in society. In this sense, we should positively assess mobility which increases with age. It indicates entering the labor market by successive generations, better and better suited to the requirements of the labor market in the market economy.

Noteworthy also changes in the assessment of the own financial situation from the point of view of the gender of children and parents. As mentioned before, in the literature, in this context most frequently are analyzed pairs of fathers and sons. However, in Poland in the transformation period, it is worth to pay attention to the situation of mothers and daughters. Due to socio-economic changes we observe in cohort 1 increased share of mothers who - during the transition period - raised their education to a tertiary level (by studying part-time or taking part in post-graduate programs $)^{12}$ and who are active in a labor market. Such rise in the level of education and professional skills among mothers in cohort 1 should, therefore, lead to a

\footnotetext{
${ }^{12}$ Their share increased from $12 \%$ (value observed for mothers from cohort 3 ) to $24 \%$ (value observed for mothers from cohort 1).
} 
reduction in the mobility of their daughters (the mother-daughter dyads) compared with older cohorts, where mothers have lower levels of education and professional activity. Confirmation of this hypothesis is the evaluation of mobility for mother-daughter dyads. In the case of cohort 1 , it amounts to 0.36. But we observe a very significant increase in the case of successive cohorts - for cohort 2 it equals to 0.52 , and for cohort $3-0.57$. This means that the relative assessment of the financial situation of daughters in the youngest cohort is as close as possible to the assessment of their mothers - in comparison with mother-daughter dyads in older cohorts.

\section{Conclusion}

In the article, we tried to answer two questions concerning the intergenerational mobility in Poland. As long-term panel datasets are not available for Poland, we decided to run the dedicated survey, which allows us to analyze the relationship between generations of children and parents. Both generations were divided into three subgroups defined from the point of view of the age during the transformation (the early 1990s).

The first question concerned the impact of the political transformation that took place in the early 1990s in Poland, on the mobility of relative assessment of the financial situation. Results presented in the article suggest that economic transition which occurred about 25 years ago had an impact on the relative performance of analyzed cohorts on the market what resulted in significant difference in their relative financial status. We observed high mobility in the older cohorts, for which only younger (children) generation came into the labor market after the transition, what is said to cause significant differences in the adaptation to the requirements of the labor market.

The second question concerned impact of economic transition on the financial situation mobility among women. We observed differences in the situation of three generations of Polish mothers. The youngest cohort seems to be well adjusted to the new situation (what resulted in relatively smaller mobility between mothers and daughters), but two older cohorts were characterized by much higher mobility, indicating much worse adjustment.

\section{Acknowledgement}

The authors would like to acknowledge the financial support of Polish National Science Centre (Grant "Resourcefulness of Polish Families", No. 2015/17/B/HS4/02713).

\section{References}

Azam, M. (2016). Household Income Mobility in India: 1993-2011. IZA Discussion Paper, 10308.

Azam, M., Bhatt, V. (2015). Like Father, Like Son? Intergenerational Educational Mobility in India. Demography, 52, 1929-1959.

Becker, G. (1981). Treatise on the Family. Cambridge: Harvard University Press.

Becker, G., Tomes, N. (1986). Human Capital and the Rise and Fall of Families. Journal of Labor Economics, 4, S1-S39.

Björklund, A., Salvanes, K. (2011). Education and Family Background: Mechanisms and Policies. In: Handbook of the Economics of Education, 3, E. Hanushek, S. Machin and L. Woessmann (eds.), Amsterdam: North Holland, 201-247.

Black, S., Devereux, P. (2011). Recent Developments in Intergenerational Mobility. In: Handbook of Labor Economics, 4B, D. Card and O. Ashenfelter (eds.), Amsterdam: North Holland, 1487-1541. 
Black, S., Devereux, P., Salvanes, K. (2005). Why the Apple Doesn't Fall Far: Understanding Intergenerational Transmission of Human Capital. American Economic Review, 95, $437-$ 449.

Blau, P., Duncan, O. (1967). The American Occupational Structure. New York: Wiley.

Bratberg, E., Davis, J., Mazumder, B., Nybom, M., Schnitzlein, D., Vaage, K. (2017). A Comparison of Intergenerational Mobility Curves in Germany, Norway, Sweden, and the US. Scandinavian Journal of Economics, 119, 72-101.

Broom, L., Jones, F. (1969). Father-to-Son Mobility: Australia in Comparative Perspective. American Journal of Sociology, 74, 333-342.

Carneiro, P., Meghir, C., Parey, M. (2013). Maternal Education, Home Environments, And The Development Of Children And Adolescents. Journal of the European Economic Association, 11, 123-160.

Central Statistical Office (2014). Gospodarstwa domowe $i$ rodziny. Charakterystyka demograficzna. Narodowy Spis Powszechny Ludności i Mieszkań 2011. Warszawa: Zakład Wydawnictw Statystycznych.

Central Statistical Office (2015). Rocznik Demograficzny 2015. Warszawa: Zakład Wydawnictw Statystycznych.

Chevalier, A. (2004). Parental education and child's education: A natural experiment. IZA Discussion Paper, 1153.

Currie, J., Almond, D. (2011). Human capital development before age five. In: Handbook of Labor Economics, 4B, D. Card and O. Ashenfelter (eds.), Amsterdam: North-Holland, 1315-1486.

Domański, H. (2004). O ruchliwości społecznej w Polsce. Warszawa: Instytut Filozofii i Socjologii PAN.

Erikson, R., Goldthorpe, J. (1992). The Constant Flux: A Study of Class Mobility in Industrial Societies. Oxford: Clarendon.

Gregg, P., Jonsson, J., Macmillan, L., Mood, C. (2013). Understanding income mobility: the role of education for intergenerational income persistence in the US, UK and Sweden. DoQSS Discussion Paper, 13-12, UCL Institute of Education.

Heckman, J., Mosso, S. (2014). The Economics of Human Development and Social Mobility. NBER Working Paper, 19925.

Jäntti, M., Jenkins, S. (2014). Income Mobility. ECINEQ Working Paper, 319.

Jenkins, S. (2011). Changing Fortunes: Income Mobility and Poverty Dynamics in Britain. Oxford: Oxford University Press.

Kośny, M., Peternek, P. (2011). Wielkość próby a istotność wnioskowania statystycznego. Didactics of Mathematics, 8(12), 71-80.

Lipset, S., Bendix, R. (1964). Social Mobility in Industrial Society. Berkeley: University of California Press.

Mach, B. (2004). Intergenerational Mobility in Poland: 1972-88-94. In: Social Mobility in Europe, R. Breen (ed.), Oxford: Oxford University Press, 269-286.

Meyer, J., Tuma, N., Zagórski, K. (1979). Education and Occupational Mobility: A Comparison of Polish and American Men. American Journal of Sociology, 84, 978-986.

Modalsli, J. (2017). Intergenerational Mobility in Norway 1865-2011. Scandinavian Journal of Economics, 119, 34-71.

Nunn, A. (2011). Draft Report on Fostering Social Mobility as a Contribution to Social Cohesion. European Committee of Social Cohesion (CDCS), Strasbourg, http://www.coe.int/t/dg3/socialpolicies/source/ECDCS\%20(2011)\%204\%20Draft\%20re port\%20on\%20social\%20mobility.doc, accessed 15.08.2017.

Shorrocks, A. (1978). The measurement of mobility. Econometrica, 46, 1013-1024. 
Sokołowska, K. (2013). Analiza czynników wpływających na mobilność społeczną w Polsce w latach 1992-2008, z wykorzystaniem modeli logitowych. Zeszyty Naukowe Wyższej Szkoty Bankowej we Wrocławiu, 2(34), 361-378. 